\title{
Assessment of Serum Cystatin C as an Early Biomarker of Carotid Atherosclerosis
}

\author{
MIRELA GRIGORAS ${ }^{1}$, DANIEL LIGHEZAN ${ }^{1}$, ROXANA FOLESCU ${ }^{1 *}$, COSMIN IOAN FAUR ${ }^{1}$, SIMINA DEJ ICA ${ }^{1}$, PATRICIA NICOLA ${ }^{1}$, \\ GEORGE DAHMA ${ }^{1}$, TEIM BAA ${ }^{1}$, IOAN TILEA ${ }^{2}$, ANDREEA VARGA ${ }^{2}$, ELENA ARDELEANU ${ }^{1}$, ALINA MIHAELA PASCU ${ }^{3 *}$, \\ VLADIMIR POROCH ${ }^{4,5 *}$, DANIELA GURGUS ${ }^{1}$ \\ 1 Victor Babes University of Medicine and Pharmacy Timisoara, 2 Eftimie Murgu Sq, 300041, Timisoara, Romania \\ 2 University of Medicine and Pharmacy Tirgu Mures, 38 Gheorghe Marinescu Sq, 540139, Targu Mures, Romania \\ ${ }^{3}$ Transilvania University of Brasov, Faculty of Medicine, 29 Eroilor Blvd, 500036, Brasov, Romania \\ ${ }^{4}$ Grigore T. Popa University of Medicine and Pharmacy, Faculty of Medicine, 16 Universitatii Str., 700115, Iasi, Romania \\ ${ }^{5}$ Regional Institute of Oncology, 2-4 G-ral Berthelot Str., 700483, Iasi, Romania
}

\begin{abstract}
The aim of this study was to establish the correlation between the value of serum cystatin $C$ (Cys $C$ ) and carotid atherosclerosis in patients without chronic kidney disease and to determine the serum Cys C cut-off level for carotid atherosclerosis diagnosis. The study was performed between October 2014 and J une 2018, and included 256 patients from 20 family medicine offices of Timis County, both from urban and rural areas. The patients completed a socio-demographic questionnaire, and were clinically examined by their general practitioner and investigated by laboratory tests and carotid ultrasound. The mean age of the patients with high serum Cys C (study group 1) was 74 years (82\% male), while in study group 2 (with low serum Cys C values) the mean age was 56 years old (63\% male). Cys C levels were significantly correlated with serum creatinine and estimated glomerular filtration rate. In the group with elevated levels of Cys $C$ we found an increased incidence of obesity, hypertension, diabetes and carotid atherosclerosis. Multivariate analysis showed that the increased levels of Cys $C$ were associated with a maximum carotid plaque thickness (MCPT) $\geq 2 \mathrm{~mm}$ (OR: 2.86, 95\% C.I.: 1.13-7.97). The serum Cys C cut-off level for the diagnosis of atherosclerosis determined by ROC (receiver operating characteristic) curve was $0.73 \mathrm{mg} / \mathrm{dL}$.
\end{abstract}

Keywords: Cystatin C; atherosclerosis; maximum carotid plaque thickness

Atherosclerosis is an important health problem, representing the main cause of morbidity and mortality worldwide [1-3]. According to the World Health Organization, 17 million people die annually because of cardiovascular disease. It is estimated that this represents a growing problem and that in 2030 more than 23 million deaths will annually occur because of cardiovascular disease [3, 4]. Early detection of atherosclerosis, prevention and treatment are important in public health. The anklebrachial index, the pulse-wave velocity and ultrasonographic investigations were introduced as useful methods in vascular atherosclerosis assessment [4-6]. Carotid atherosclerosis may be estimated by intima-media thickness (IMT), which can be easily measured by B-mode ultrasonography (non-invasively) [7, 8]. IMT represents a marker of systemic subclinical atherosclerosis used in many studies as a strong predictor of myocardial infarction and stroke $[9,10]$. Some published data considered the carotid plaque as a stronger vascular predictor of atherosclerosis than the carotid IMT [11, 12]. The maximum carotid plaque thickness (MCPT), that can be used to evaluate atherosclerotic vascular changes, was associated with an increased risk of vascular morbidity in some reported studies $[13,14]$.

Cystatin C (Cys C) is a nonglycosylated basic protein of the cysteine proteinase inhibitors produced byall nucleated cells. The low molecular mass of Cys $\mathrm{C}$, in combination with its stable production rate, strongly suggests that serum Cys $C$, determined by a rapid, au-tomated particleenhanced turbidimetric meth-od, is a better marker than serum creatinine for glomerular filtration rate (GFR). The use of Cys $C$ in addition to creatinine improves the estimation of GFR, turning it independent of vague terms like race and gender, and facilitates its use for both children and adults, including the elderly. The low-cost analysis of Cys $C$ should be an integral part of the analysis spectrum for optimal evaluation of the kidney status of a patient [14].

Cys $C$ serum levels have been recently proposed as biomarkers for atherosclerosis and chronic kidney disease. Elevated serum Cys $C$ values represent useful biomarkers in identifying an increased risk of cardiovascular disease and increased mortality in patients whose serum creatinine levels and estimated glomerular filtration rate (eGFR) indicate a low cardio-vascular risk $[15,16]$. A retrospective study showed that atherosclerotic changes associated with inflammation may have the same pathogenic mechanism as the association between serum Cys $C$ and cardiovascular disease $[17,18]$. The association between serum Cys $\mathrm{C}$ and atherosclerotic changes remains controversial, and the diagnostic cut-off value of serum Cys $\mathrm{C}$ for atherosclerosis still needs further research as previous studies associating serum Cys $C$ and the maximum carotid plaque thickness are limited [19, 20].

The aim of the present study was to establish the correlation between serum Cys $C$ and carotid atherosclerosis and to identify a reference value for serum Cys $C$ suggestive for atherosclerosis development [21, 22].

\section{Experimental part \\ Materials and methods \\ This cross sectional observational study was performed between October 2014 and J une 2018, and enrolled 270 patients (adults and elderly) from 20 family medicine offices in Timis County, both from urban and rural areas. Fourteen patients were excluded because of the lack of the carotid ultrasound investigations. Finally a total of 256}

*email: oxanafolescu08@gmail.com, alina.pascu@unitbv.ro and vlader2000@yahoo.com 
patients (192 men and 64 women), with an average age of 68 years (range 40-85 years) were considered eligible for the evaluation. All the included subjects were asked to complete a questionnaire related to their sociodemographic characteristics, personal pathological history (diabetes, hypertension, dyslipidemia) as well as lifestyle factors (smoking, physical activity, alcohol consumption). In accordance to the rules of the Helsinki Declaration, each participant signed a written informed consent, as stated in some reported models [20-25]. The study was approved by the Ethics Committee of the Victor Babes University of Medicine and Pharmacy Timisoara.

Height, weight and abdominal circumference were measured, and the body mass index (BMI) was calculated using the formula:

$$
\mathrm{BMI}=\text { weight/height }{ }^{2}\left[\mathrm{~kg} \cdot \mathrm{m}^{-2}\right] \text {. }
$$

Systolic (SBP) and diastolic blood pressure (DBP) were measured in seated position after 15 min of rest in the GPs offices, using the semiautomatic Omron HEM 7251G device in all offices.

Laboratory data included fasting plasma glucose (FPG) assessment, glycated hemoglobin, Alc isoform (HbAlc), total cholesterol (TC), high density lipoprotein cholesterol (HDL-C), triglycerides (Trigl), creatinine (Creat), and cystatin C (Cys C).

Cys $\mathrm{C}$ was determined by a rapid, au-tomated particleenhanced turbidimetric meth-od. Low density lipoprotein cholesterol (LDL-c) plasma levels were estimated using the Friedewald formula:

$$
\text { LDL-C }=\mathrm{TC}-[\mathrm{HDL}-\mathrm{C}+(\text { Trigl/5) }]
$$

The estimated glomerular filtration rate (eGFR) was calculated based on the recommendations of the KDIGO 2012 Guidelines, using the CKD-EPI (Chronic Kidney Disease Epidemiology Collaboration) 2009 based on 4 variables - serum creatinine concentration, age, gender and race, adjusting GFR to body surface area:

$$
\begin{gathered}
\mathrm{eRFG}\left[\mathrm{mL} / \mathrm{min} / 1.73 \mathrm{~m}^{2}\right]= \\
141 \times \min (\mathrm{SCreat} / \mathrm{k}, 1)^{\alpha} \times \max \left(\mathrm{SCreat}^{\prime} / \mathrm{k}, 1\right)^{-1.209} \mathrm{x} \\
\times 0.993^{\mathrm{Age}} \times 1.018 \text { [if female], }
\end{gathered}
$$

where: SCreat is serum creatinine (expressed in $\mathrm{mg} / \mathrm{dL}$ ), $k$ is 0.7 for women and 0.9 for males, $\alpha$ is -0.329 for females and -0.411 for males, min is the minimum of SCreat/k ratio or 1, and max is the maximum of SCreat/k ratio or 1.

$\mathrm{HbAlc}$ was calculated according to the National Glycohemoglobin Standardization Program (NGSP) protocol, using a correction formula:

$$
{ }^{\prime} \% \mathrm{HbAlc}=(\mathrm{HbAlc} / \mathrm{Hb}) \times 91.5+2.15 .
$$

Unhealthy lifestyle behaviors were defined as daily alcohol consumption, smoking and sedentary lifestyle.

Diabetes mellitus was diagnosed using one of the following criteria: $\mathrm{HbAlc} \geq 6.5 \%$, fasting plasma glucose (FPG) $\geq 126 \mathrm{mg} / \mathrm{dL}$ or current therapy with antidiabetic agents.

Hypertension was defined as SBP $\geq 140 \mathrm{mmHg}$ and/or $\mathrm{DBP} \geq 90 \mathrm{mmHg}$ or current antihypertensive treatment.

Carotid atherosclerosis was assessed using a Sonoscape SS 8000 device, which determined automatically the intima-media thickness (IMT) and the thickness of the carotid plaque. The carotid plaque was defined by a focal IMT > $1.4 \mathrm{~mm}$. Maximum carotid plaque thickness (MCPT) was defined as the maximum peak of the carotid artery prominence on any segment of the common carotid artery. Carotid atherosclerosis was defined by $M C P T \geq 2 \mathrm{~mm}$.

\section{Statistical analysis} 12.0 .

Statistical analysis was performed using SPSS version

Demographic characteristics were compared using Student t test for continuous variables and chi-square test for categorical variables.

The serum Cys $C$ cut-off level for the diagnosis of atherosclerosis was determined by receiver operating characteristic (ROC) curve analysis, with the Youden index.

Multiple logistic regression analysis with adjustments for age and gender was conducted to determine the correlations between a MCPT $\geq 2 \mathrm{~mm}$ and metabolic variables including Cys $\mathrm{C}$ levels. The results of the study were expressed as medians of the non-parametric variables and considered significant when $P$ value was < 0.05 .

\section{Results and discussions}

The demographic and clinical characteristics of the study group population are shown in table 1.

Table 1

BASELINE DEMOGRAPHIC AND CLINICAL CHARACTERISTICS OF THE STUDY POPULATION

\begin{tabular}{|l|c|}
\hline Variables & \\
\hline Age [yr] - [mean (min, max)] & $68(40-85)$ \\
\hline Gender (male) - [n (\%)] & $192(75 \%)$ \\
\hline BMI [kg/m] - [mean (min, max)] & $32.2(18.6-34.2)$ \\
\hline Current smokers - [n (\%)] & $62(24 \%)$ \\
\hline Alcohol consumption - [n (\%)] & $148(58 \%)$ \\
\hline Sedentary lifestyle - [n (\%)] & $204(80 \%)$ \\
\hline SBP [mmHg] - [mean (min, max)] & $132(92-180)$ \\
\hline DBP [mmHg] - [mean (min, max)] & $74(55-94)$ \\
\hline Antihypertensive treatment - [n (\%)] & $140(54 \%)$ \\
\hline Antidiabetic treatment - [n (\%)] & $87(34 \%)$ \\
\hline Diagnosed dyslipidemia - [n (\%)] & $154(60 \%)$ \\
\hline
\end{tabular}

The biochemical characteristics of the study population are shown in table 2.

Table 2

BIOCHEMICAL CHARACTERISTICS OF THE STUDY POPULATION

\begin{tabular}{|l|c|}
\hline Biochemical parameters & Mean value (min, max) \\
\hline Fasting plasma glucose [mg/dL] & $102(86-302)$ \\
\hline Hb A1c [\%] & $5.6(4.6-9.2)$ \\
\hline TC [mg/dL] & $202.6(134-618)$ \\
\hline HDL-c [mg/dL] & $44(32-86)$ \\
\hline LDL-c [mg/dL] & $128(58-216)$ \\
\hline Trigl $[\mathrm{mg} / \mathrm{dL}]$ & $152(96-864)$ \\
\hline Creat $[\mathrm{mg} / \mathrm{dL}]$ & $0.82(0.28-1.62)$ \\
\hline eGFR [mL/min/1.73 $\left.\mathrm{m}^{2}\right]$ & $68.6(42.6-128.4)$ \\
\hline Cys C [mg/L] & $0.76(0.48-1.46)$ \\
\hline
\end{tabular}

See text for abbreviations 


\begin{tabular}{|c|c|c|c|}
\hline Variable & $\begin{array}{c}\text { Group l } \\
\text { (serum Cystatin C } \\
\geq 0.73 \mathrm{mg} / \mathrm{dL} \text { ) } \\
\mathrm{n}=158\end{array}$ & $\begin{array}{c}\text { Group 2 } \\
\text { (serum Cystatin C } \\
<0.73 \mathrm{mg} / \mathrm{dL} \text { ) } \\
\mathrm{n}=98\end{array}$ & $P$ value \\
\hline Age [yr] - [mean (min, max)] & $74(42-84)$ & $56(40-78)$ & $<0.01^{1}$ \\
\hline Gender (male) - [n (\%)] & $130(82 \%)$ & $62(63 \%)$ & $<0.01^{2}$ \\
\hline BMI $\left(\mathrm{kg} / \mathrm{m}^{2}\right)-[\operatorname{mean}(\min , \max )]$ & $28.4(18.2-30.6)$ & $22.8(16.4-24.2)$ & $<0.01^{1}$ \\
\hline Smokers - $[\mathrm{n}(\%)]$ & $44(28 \%)$ & $18(18 \%)$ & $0.84^{2}$ \\
\hline Alcohol consumption - [n (\%)] & $88(56 \%)$ & $62(64 \%)$ & $0.68^{2}$ \\
\hline Sedentary lifestyle - [n(\%)] & $102(64 \%)$ & $46(47 \%)$ & $0.26^{2}$ \\
\hline Diagnosed hypertension - [n (\%)] & $98(62 \%)$ & $42(43 \%)$ & $<0.01^{2}$ \\
\hline Diagnosed diabetes mellitus - $[\mathrm{n}(\%)]$ & $60(38 \%)$ & $27(28 \%)$ & $<0.01^{2}$ \\
\hline Diagnosed dyslipidemia - $[\mathrm{n}(\%)]$ & $92(58 \%)$ & $62(63 \%)$ & $0.82^{2}$ \\
\hline Creat [mg/dL] - [mean (min, max)] & $0.82(0.46-1.38)$ & $0.64(0.34-1.16)$ & $<0.01^{1}$ \\
\hline eGFR $\left[\mathrm{mL} / \min / 1.73 \mathrm{~m}^{2}\right]-[\operatorname{mean}(\min , \max )]$ & $68.8(40.2-104.6)$ & $82.6(58.8-116.2)$ & $<0.01^{1}$ \\
\hline $\mathrm{MCPT} \geq 2 \mathrm{~mm}-[\mathrm{n}(\%)]$ & $88(56 \%)$ & $20(20 \%)$ & $<0.01^{2}$ \\
\hline
\end{tabular}

Table 3

CHARACTERISTICS OF THE TWO STUDY GROUPS IN ASSOCIATION WITH SERUM CYSTATIN C LEVELS

Student $t$ test $^{2} \chi^{2}$ test.

A serum Cys C cut-off value $\geq 0.73 \mathrm{mg} / \mathrm{dL}$ was identified on the ROC curve as relevant for carotid atherosclerosis, with a sensitivity of $82.7 \%$, and a specificity of $52.6 \%$, a positive predictive value of $54 \%$, and a negative predictive value of $82 \%$.

The study population was divided into two groups by the serum Cys C cut-off value identified by the ROC curve as significant for carotid atherosclerosis: group 1 ( $n=158)$ including patients with carotid atherosclerosis (serum Cys $C \geq 0.73 \mathrm{mg} / \mathrm{dL})$ - and group $2(\mathrm{n}=98)$ - patients with serum Cys $\mathrm{C}<0.73 \mathrm{mg} / \mathrm{dL}$, withoutcarotid atherosclerosis.

The characteristics of the two study groups based on serum Cys $C$ values are shown in table 3. BMI, hypertension, diabetes mellitus and MCPT were significantly higher in group 1 compared to the group 2 (figs.1 and 2). Regarding the lifestyle habits, the sedentary lifestyle was more frequent in group 1 . The eGFR was significantly lower in group 1.

The present study also found differences in characteristics between subjects with MCPT $\geq 2 \mathrm{~mm}$, compared to patients with MCPT $<2 \mathrm{~mm}$ (table 4). Age, hypertension, diabetes, Creat, and Cys C were significantly higher in the MCPT $\geq 2 \mathrm{~mm}$ subgroup. Furthermore, eGFR was significantly lower in the MCPT $\geq 2 \mathrm{~mm}$ subgroup. The lifestyle habits of the two subgroups did not differ significantly.

\begin{tabular}{|c|c|c|c|}
\hline Variables & $\begin{array}{c}\text { Subgroup 1 } \\
\text { (MCPT } \geq 2 \mathrm{~mm}) \\
\mathrm{n}=108\end{array}$ & $\begin{array}{c}\text { Subgroup 2 } \\
\text { (MCPT }<2 \mathrm{~mm} \text { ) } \\
\mathrm{n}=148\end{array}$ & $P$ value \\
\hline & $\mathrm{MCPT} \geq 2 \mathrm{~mm}$ & & \\
\hline Age [yr] - [mean (min, $\max )]$ & $74(52,84)$ & $68(40,85)$ & $<0.01^{1}$ \\
\hline Gender (male) - [n (\%)] & $88(88 \%)$ & $104(70 \%)$ & $<0.34^{2}$ \\
\hline $\mathrm{BMI}\left(\mathrm{kg} / \mathrm{m}^{2}\right)-[\operatorname{mean}(\min , \max )]$ & $26.2(18.6-36.2)$ & $25.8(20.2-34.4)$ & $<0.34^{1}$ \\
\hline Smokers - [n (\%)] & $26(24 \%)$ & $36(24 \%)$ & $0.86^{2}$ \\
\hline Alcohol consumption - [n (\%)] & $58(54 \%)$ & $90(60 \%)$ & $0.18^{2}$ \\
\hline Sedentary lifestyle - [n (\%)] & $104(96 \%)$ & $100(68 \%)$ & $0.32^{2}$ \\
\hline Diagnosed hypertension - [n (\%)] & $74(68 \%)$ & $66(45 \%)$ & $<0.01^{2}$ \\
\hline Diagnosed diabetes mellitus - $[\mathrm{n}(\%)]$ & $50(46 \%)$ & $37(25 \%)$ & $<0.01^{2}$ \\
\hline Diagnosed dyslipidemia - $[\mathrm{n}(\%)]$ & $67(62 \%)$ & $87(59 \%)$ & $0.94^{2}$ \\
\hline Creat $[\mathrm{mg} / \mathrm{dL}]-[$ mean $(\min , \max )]$ & $0.82(0.46-1.32)$ & $0.76(0.38-1.22)$ & $<0.03^{1}$ \\
\hline eGFR $\left[\mathrm{mL} / \min / 1.73 \mathrm{~m}^{2}\right]-[\operatorname{mean}(\min , \max )]$ & $72.4(42.6-112.8)$ & $82.4(48.6-126.2)$ & $<0.02^{1}$ \\
\hline Cys C $[\mathrm{mg} / \mathrm{dL}]-[\mathrm{n}(\%)]$ & $0.84(0.56-1.42)$ & $0.72(0.48-1.32)$ & $<0.01^{1}$ \\
\hline
\end{tabular}

Table 4

STUDY POPULATION CHARACTERISTICS IN ASSOCIATION WITH MCPT 


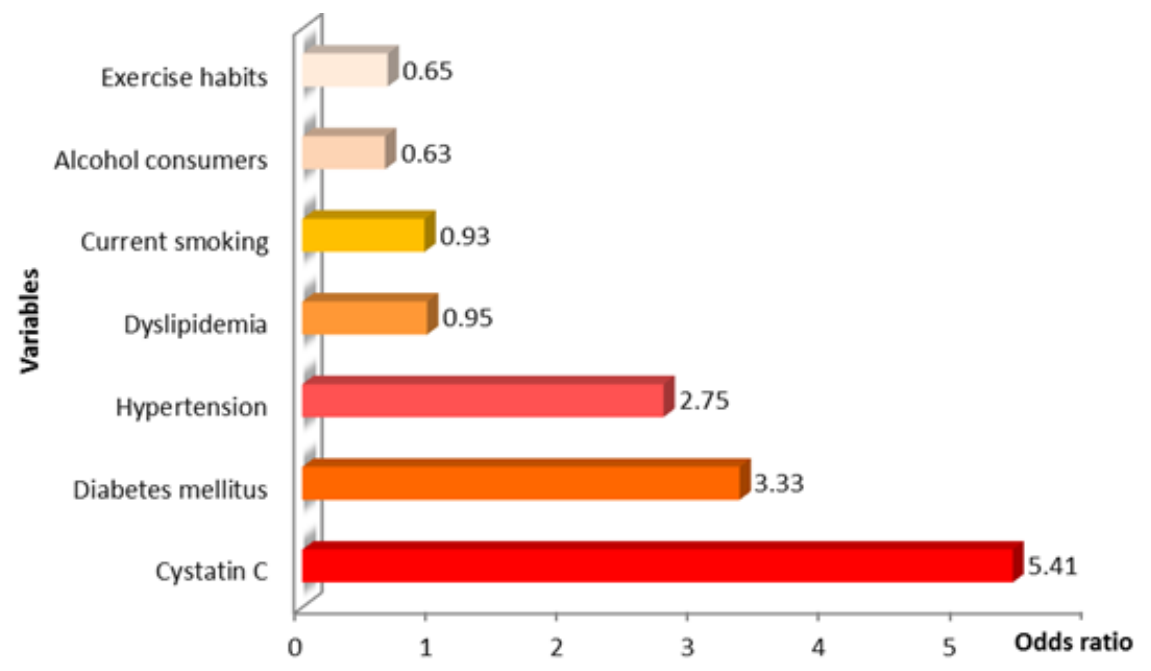

Fig. 3. Variables associated MCPT $\geq 2 \mathrm{~mm}$

The variables associated with a MCPT $\geq 2 \mathrm{~mm}$ are shown in figure 3. Multivariate analysis, adjusted for age and gender, revealed that high serum Cys $C$ levels were most significantly associated with a MCPT $\geq 2 \mathrm{~mm}$ (OR: 2.86; 95\% C.I.: 1.13-7.97) (table 5).

Serum Cys $C$ levels were reported to correlate significantly with eGFR and proved more sensitive in detecting early impairment of renal function than serum creatinine [26-28]. Our results support this hypotensis, as serum Cys $C$ values were significantly correlated with eGFR. The eGFR was significantly lower in the increased Cys $C(\geq 0.73 \mathrm{mg} / \mathrm{dL})$ group. A cross-country study in Netherlands on 8.058 patients showed that the serum concentration of Cys $\mathrm{C}$ was also influenced by other factors such as age, gender and BMI [29-31]. Correlated to the age, serum Cys $C$ levels were demonstrated to be higher in older individuals. In our study the mean age of patients in group 1 (serum Cys C above the cut-off level of $0.73 \mathrm{mg} /$ $\mathrm{dL}$ ) was 74 years old, while in group 2 it was 56 years. The observed association between male gender, $\mathrm{BMI}$, and higher levels of Cys $C$ were also consistent with other published data [32, 33]. Parikh et al. [34] evaluated the association between Cys $\mathrm{C}$ and conventional cardiovascular risk factors in 3.241 predominantly Caucasian participants in the Framingham offspring prospective cohort study [34-37]. The authors showed that high concentrations of Cys $C$ were independently associated with cardiovascular risk factors such as age, gender, BMI, low HDL cholesterol, hypertension and smoking. Our results showed an increased incidence of obesity, hypertension and dyslipidemia in the study group 1 , with Cys $C$ levels above cut-off. The association between Cys $\mathrm{C}$ and incident hypertension has been prospectively studied in a cohort of individuals from the Multi-Ethnic Study of Atherosclerosis [30, 38, 39]. Kestenbaum et al. [35] evaluated whether early kidney dysfunction measured by serum Cys $\mathrm{C}$ might be a risk factor for new-onsethypertension. The association between Cys $\mathrm{C}$ and incidenthypertension was similar when patients with eGFR $\geq 90 \mathrm{~mL} / \mathrm{min} / 1.73 \mathrm{~m}^{2}$ were considered. Our results did not overlap to this study, both patients in group 1 and group 2 showing hypertension at slightly increased eGFR $\geq 75 \mathrm{~mL} / \mathrm{min} / 1.73 \mathrm{~m}^{2}$, possibly by involving other risk factors. In the Uppsala Longitudinal Study of Adult Men, Zethelius et al. [37] assessed whether a combination of biomarkers including Cys $\mathrm{C}$ improved patients' risk stratification compared to established cardiovascular risk factors [40-42]. For the whole patients group (including well established biomarkers / or not) the area under the ROC curve was 0.766 , and, respectively, $0.664, P<0.001$. The areas under the ROC curve for the group without cardiovascular disease at baseline were 0.748 and 0.688 , respectively $(P=0.03)$, and for established risk factors with and without $C y s \mathrm{C}$ considered in the model, 0.691 vs. $0.664, P=0.07)$. The prognostic value of serum Cys $C$ cut-off level $=0.73 \mathrm{mg} / \mathrm{dL}$ identified in our study was different possibly because of using age and gender adjustments in the multivariate analysis.

In a recent Japanese study, Yamashita et al. [28] attempted to clarify the association between Cys $C$ and arteriosclerosis in the absence of chronic kidney disease in 637 patients, observing a strong correlation between Cys $C$ and the cardio-ankle vascular index, which is an early marker for the detection of atherosclerosis in women [43]. Our results were differently due to the fact that our study group included more men and the parameters used to define atherosclerosis were differently.

In a cross-sectional study including 133 Japanese subjects who underwent an inpatient medical health checkup at J untendo University Hospital, Kobayashi et al. [38], investigated the correlation between carotid

\begin{tabular}{|l|c|c|c|c|}
\hline \multirow{2}{*}{ Variables } & \multicolumn{2}{c|}{ Univariate analysis } & \multicolumn{2}{c|}{ Multivariate analysis $^{1}$} \\
\cline { 2 - 5 } & Odds ratio & $\mathbf{9 5 \%}$ C.I. & Odds ratio & $\mathbf{9 5 \%}$ C.I. \\
\hline Cystatin C & 5.41 & $2.29-12.37$ & 2.86 & $1.13-7.97$ \\
\hline Diabetes mellitus & 3.33 & $1.31-7.39$ & 1.92 & $0.69-4.84$ \\
\hline Hypertension & 2.75 & $1.28-5.36$ & 1.58 & $0.66-3.50$ \\
\hline Dyslipidemia & 0.95 & $0.45-1.95$ & & \\
\hline Current smoking & 0.93 & $0.34-2.32$ & & \\
\hline Alcohol consumption & 0.63 & $0.27-1.27$ & & \\
\hline Sedentary lifestyle & 0.65 & $0.33-1.47$ & & \\
\hline Adjusted for age and gender & & & & \\
\hline
\end{tabular}

Table 5

MULTIPLE LOGISTIC REGRESSION OF THE STUDY POPULATION CHARACTERISTICS ASSOCIATED WITH $M C P T \geq 2 \mathrm{~mm}$ 
atherosclerosis and Cys C [44-47]. They demonstrated that increased levels of Cys $C$ were associated with carotid atherosclerosis. In our present study, multivariate analysis showed thatelevated serum Cys $C$ values were significantly associated with carotid atherosclerosis, defined by MCPT $\geq 2 \mathrm{~mm}$, referring to middle-age and elderly population.

There are several possible explanations for the association of Cys $\mathrm{C}$ and atherosclerotic lesions. First, inflammation may be associated to both Cys $C$ increase and atherosclerosis [48]. The Cardiovascular Health Study, which included 4.637 elderly ambulatory patients, demonstrated a linear correlation of $\mathrm{Cys} C \mathrm{C}$ with $\mathrm{C}$-reactive protein serum concentration, but not with Creat and eGFR [32]. It is well known that inflammation contributes to atherogenesis, atherosclerotic plaque progression and acute coronary syndrome. Cys C plays an important role in stabilizing the atheromatous plaque. A previous study of 31 atheroma plaques extracted by endarterectomy demonstrated that human carotid plaques contained Cys C localized within collagen and elastin, identified by immunohistochemistry [33]. In vascular diseases, such as atherosclerosis and abdominal aortic aneurysm, interference between cysteine protease and Cys $\mathrm{C}$ and arterial wall remodeling was noticed [34].

The present study has certain limits. The subjects were selected from a limited area in the western part of our country, not representative of the entire population of our country. Also, the study sample was small. The evaluation of the patients' lifestyle by questionnaires was subjective, depending on the patients' declarations.

\section{Conclusions}

In the present study serum cystatin C levels correlated significantly with eGFR and proved more sensitive in detecting early impairment of renal function.

The association between age and serum cystatin $\mathrm{C}$ levels showed that serum cystatin C levels were higher in older individuals.

Our results showed an increased incidence of obesity, hypertension and dyslipidemia in the study group with elevated levels of cystatin C.

The elevated serum Cys C levels correlated with carotid atherosclerosis defined by MCPT $\geq 2 \mathrm{~mm}$ in middle-aged and elderly subjects. Elevated serum Cys $C$ values $(\geq 0.73$ $\mathrm{mg} / \mathrm{dL}$ ) demonstrated a low specificity, but a high sensitivity and can therefore be useful for excluding atherosclerosis. The cut-off Cys C serum level $=0.73 \mathrm{mg} /$ $\mathrm{dL}$ proved useful in the early diagnosis of atherosclerosis. Therefore atherosclerosis might be early identified by a simple blood test. Assessment of serum Cys $\mathrm{C}$ might be recommended as part of routine periodical screening investigations in general population, notonly as a biomarker of chronic kidney disease, but also as a predictor of atherosclerosis.

\section{References}

1.WANG, H., MURRAY, J.L.C., LOPEZ, A., GBD 2015, The Lancet, 4, no. 10, 2016, p. 117.

2.LASLETT, L.J., ALAGON, P., CLARK, B.A., DROZDA, J.P., SALDIVAR, F., WILSON, SR., POE, C., HART, M., JACC, 60, no. 25, 2012, p. 37. 3.BUDA, V., MINODORA A., CRISTESCU, C., VOICU, M., SUCIU, L., MUNTEAN, C., CRETU, O., BAIBATA, D.E., GHEORGHIU, C.M., TOMESCU, M.C., Farmacia, 64, no. 3, 2016, p. 382.

4.GERHARD-HERMAN, M D., GORNIK, H L. et al., JACC, 69, no. 11, 2017, p. 1478.

5.VLACHOPOULOS, C., AZNAOURIDIS, K., STEFANADIS, C., European Heart J ournal, 31, no. 15, 2010, p. 1318.
6.OANCEA, R., PODARIU, A.C., VASILE, L., SAVA-ROSIANU, R., FOLESCU, R., Rom. J. Morphol. Embryol. 54, no. 2, 2013, p. 333.

7.YEBOAH, J., .FOLSOM, AR., BURKE, G.L., JOHNSON, C., POLAK, J.F., POST, W., LIMA, J.A., CROUSE, JR., HERRINGTON, D.M., Circulation, 120, no. 6, 2009, p. 502.

8.NEAMTU, C., TOTOLICI, B.D., CRETU, O.M., STANESCU, C., ARDELEAN, A., BADEA, O., PRIBAC, G.C., CIOBANU, M.O., MATEESCU, G.O., MOGOANTA, S.S., Rom. J. Morphol. Embryol., 2017, 58, no. 1, p. 235.

9.LORENZ, M.W., VON KEGLER, S., STEINMETZ, H., MARKUS, H.S., SITZER, M., Diabetes Care, 38, no. 10, 2015, p. 1921.

10.FOLESCU, R., ZAMFIR, C.L., SISU A.M., MOTOC, A.G.M., ILIE, A.C., MOISE, M., Rom. J. Morphol. Embryol., 55, no. 3, 2014, p. 797.

11.KITAGAWA, K., HOUGAKU, H., YAMAGAMI, H., HASHIMOTO, H., ITOH, T., Cerebrovasc. Dis., 24, no. 1, 2007, p. 35.

12.BUDA, V., ANDOR, M., PETRESCU, L., CRISTESCU, C, BAIBATA, D.E., VOICU, M., MUNTEANU, M., CîTU, I., MUNTEANU, C., CREU, O., TOMESCU, M.C., Int. J. Mol. Sci., 18, no. 2, 2017, p 348. doi: 10.3390/ ijms18020348.

13.SAXENA, Y., SAXENA, V., MITTAL, M., SRIVASTAVA, M., RAGHUVANSHI S., Ann. Neurosci., 24, no. 4, 2017, p. 5.

14.DEN RUIJTER, H.M., PETERS, S.A., ANDERSON, TJ. et al., JAMA, 308, no. 8, 2012, p. 796.

15.MOISE M., BURUIAN M. M., ILIE C., ZAMFIR C.L., FOLESCU R., MOTOC A. G. M., Rom. J. Morphol. Embryol., 54, no. 4, 2013, pp. 961968.

16.HERDER, M., J OHNSEN, S.T., ARNTZEN, K.A., MATHIESEN, E., Stroke, 43, no.7, 2012, p. 1818.

17.RUSU, M.C., CERGAN R., DERMENGIU, D., CURCA, G.C., FOLESCU, R., MOTOC, A.G., JIANU, A.M., Clin. Anat., 23, no.1, 2010, p. 93.

18.SARNOWSKI, B., LUDEMANN, J., VOLZKE, H., DORR, M., KESSLER, C. SCHMINKE, U., Stroke, 41, no. 10, 2010, p. 2375.

19.FAUR, A.C., SAS, I., MOTOC, A.G.M., CORNIANU, M., ZAMFIR, C.L., LAZAR, D.C., FOLESCU, R., Rom. J. Morphol. Embryol., 56, no. 4, 2015, p. 1429.

20.RUNDEK, T., ARIF, H., BODEN-ALBALA, B., ELKIND, M.S., PAIK, M.C., SACCO, R.L., Neurology, 70, no.14, 2008, p. 1200.

21.GRUBB, A., EJIFCC, 28, no. 4, 2017, p. 268.

22.VAN DAR LAAN, S.W. et al., J. Am. Coll. Cardiol., 69, no. 9, 2016, p. 934.

23.AGHEORGHIESEI CORODEANU, D.T., POROCH, V., 6th LUMEN International Conference on Rethinking Social Action Core Values, 16-19 April 2015, lasi, Romania, Rethinking Social Action. Core Values, p. 33.

24.ROGOZEA, L., REPANOVICl, A., CRISTEA, L., BARITZ, M., MICLAUS, R., PASCU, A., Proceedings of the 4th WSEAS/IASME International Conference on Educational Technologies (Edute'08), Book Series: Recent Advances in Computer Engineering, Corfu, Greece, 2008, Oct. 26-28, p. 87.

25.POROCH, V., AGHEORGHIESEl, D.T., Postmodern Openings, 9 , no. 2, 2018, p. 225.

26.DUPONT, M., WU, Y., HAZEN, S.L., TANG, W.H., Circ. Heart, Fail., 5, no. 5,2012, p. 602.

27.IMAI, A., KOMATSU, S., OHARA, T., KAMATA, T., YOSHIDA, J., MIYAJ I, K., SHIMIZU, Y., TAKEWA, M., HIRAYAMA, A., DESHPANDE, G.A., TAKAHASHI, O., KODAMA, K., Atherosclerosis, 218, no. 2, 2011, p. 350.

28.YAMASHITA, H., NISHINO, T., OBATA, Y., NAKAZATO, M., INOUE, K., FURUSU, A., TAKAMURA, N., MAEDA, T., OZONO, Y., KOHNO, S., J. Atheroscler. Thromb., 20, no. 6, 2013, p. 548.

29.RATA, D.M., POPA, M., CHAILAN, J.F., ZAMFIR, C.L., PEPTU, A., J. Nanoparticle Res., 16, no. 8, 2014, p. 2569.

30.GARIMELLA, P.S., IX, J.H., KATZ, R., SHLIPAK, M.G., CRIQUI, M.H., SISCOVICK, D.S., KRAMER, H., SIBLEY, C.T., SARNAK, M.J., J. Kidney Dis., 65, no. 1, 2015, p. 33.

31.ALEXA, A.I., CANTEMIR, A., ANTIOCH, I., BALMUS, I.M., COJOCARU, S., GARDIKIOTIS, R., LUCA, A., FILIP, M., ABABEI, D.C., ZAMFIR, C.L., Rev. Chim. (Bucharest), 68, no. 2, 2017, p. 350. 
32.KNIGHT, E.L.,VERHAVE, J., SPIEGELMAN, D., HILLEGE, H., Kidney Int., 65, no. 4, 2004, p. 1416.

33.CRETU, O.M., HUT, E.F., DAN, R.G., SIMA L.V., BLIDISEL, C.I.A., LIGHEZAN, D.F., MUNTEANU, M., RATIU I.M., Rom. J. Morphol. Embryol., 58, no. 4, 2017, p. 1295.

34.PARIKH, N.I., HWANG, S.J., YANG, Q., LARSON, M.G., GUO, C.Y., ROBINS, S.J., Am. J. Cardiol., 102, no. 9, 2008, p. 1194.

35.KESTENBAUM, B., RUDSER, K.D., PERALTA, C.A., FRIED L.F, SHLIPAK, M.G., Ann. Intern. Med., 148, no. 7, 2008, p. 501.

36.TEMNEANU, RO., MOTOC, A., ZUGUN F.E., FOLESCU, R., LUPUSORU, C.E., ZAMFIR, C.L., Rom. J. Morphol. Embryol., 53, no. 3, 2014, p. 789.

37.ZETHELIUS, B., BERGLUND, L., SUNDSTROM, J., INGELSSON, E., BASU, S., LARSSON, A., et al., N. Engl. J. Med., 358, no. 20, 2008, p. 2107.

38.KOBAYASHI, T., YOKOKAWA, H., FUJ IBAYASHI, K., HANIU, T., World J. Cardiol., 9, no. 2, 2017, p. 174.

39.POPESCU, M.R., BUTCOVAN, D., FOLESCU, R., MOTOC, A., ZAMFIR, C.L., Romanian J. of Legal Medicine, 21, no. 3, 2013, p. 207. 40.SHLIPAK, M.G., FRIED, L.F., CRUMP, C., BLEYER, A.J., MANOLIO, T.A., TRACY, R.P., FURBERG, C.D., PSATY, B.M., Circulation, 107, no. 1, 2003, p. 87.
41.ROSCA, C., MUNTEANU, M., TAMASOI I., PETROVIC, Z., BALICA, N., NICULA C., CRETU O.M., Acta Ophthalmologica, 94, no. 6, 2016, p. 625.

42.PASCU, A., RADOI, M., COCULESCU, M., Acta Endo-Bucharest, 5, nr. 1, 2009, p. 1-18.

43.TEMNEANU, R.O., MOTOC, A., ZUGUN, F.E., FOLESCU, R., LUPUSORU, C.E., ZAMFIR, C.L., Rom. J. Morphol. Embryol., 53, no. 3, 2012, p. 789.

44.SHLIPAK, M.G., KATZ, R., CUSHMAN, M., SARNAK, M.J., STEHMANBREEN, C., PSATY, B.M., SISCOVICK, D., TRACY, R.P., NEWMAN, A., FRIED, L., Am. J. Med., 118, no. 12, 2005, p. 1416.

45.GONÇALVES, I., ARES, M.P., MOBERG, A., MOSES, J., TO, F., MONTAN, J., PEDRO, L.M., DIAS, N., FERNANDES, E., FERNANDES, J., FREDRIKSON, G.N., NILSSON, J., JOVINGE, S., BENGTSSON, E., J. Vasc. Res., 45, no. 5, 2008, p. 395.

46.SINDILAR, A., ZAMFIR, C.L., SINDILAR, E.V., PINZARIU, A.C., CRAUCIUC, E., NICULESCU, S., VESELIN, A.E.P., ZAMFIR, S.A., POROCH, V., FOLESCU, R., Rev. Chim. (Bucharest), 68, no. 6, 2017, p. 1479. 47.SHI, G.P., SUKHOVA, G.K., GRUBB, A., DUCHARME, A., RHODE, L.H., LEE, R.T., RIDKER, P.M., LIBBY, P., CHAPMAN, H.A., J. Clin. Invest., 104, 1999, p. 1191.

48.GAVRIS, C., POROCH, V., SIMION, L., BARACAN, A., TOADER, E., PASCU, A.M., Rev. Chim. (Bucharest), 68, no. 7, 2017, p. 1586.

Manuscript received: 12.07 .2018 